\title{
Application of life-cycle assessment to the eco-design of LED lighting products
}

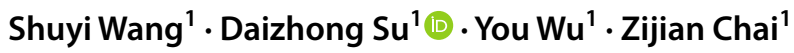

Received: 27 March 2020 / Accepted: 3 July 2020 / Published online: 31 July 2020

(c) The Author(s) 2020

\begin{abstract}
An approach for integrating life-cycle assessment (LCA) into the eco-design of lighting products was developed, and LCAs of five lighting products that are currently on the market were then carried out using this approach. Based on the results of these LCAs, the sustainability requests for lighting products were derived and embedded into the product design specification (PDS), thus ensuring that any product developed according to the PDS would have the desired eco-design features. A new sustainable lighting product was then designed according to the PDS and manufactured, after which the new product underwent LCA. Upon comparing the results of the LCA of the new product with the LCA results for the existing lighting products, the newly designed product was found to provide better environmental performance than the existing products (a $27-58 \%$ reduction in environmental impact).
\end{abstract}

Keywords Life-cycle assessment $($ LCA $) \cdot$ Eco-design $\cdot$ Environmentally sustainable design $\cdot$ Lighting product

\section{Introduction}

Reducing ecological footprints through responsible production and the efficient management of resources and waste are targets that are specified in the United Nations Sustainable Development Goals (SDGs) and were highlighted at the United Nations Climate Change Conference COP21 (Climate Action 2015). Thus, environmentally sustainable products and services are becoming increasingly important in global markets. Green Public Procurement (GPP) encourages the use of sustainable products and services (PachecoBlanco and Bastante-Ceca 2016; LeBlanc 2018). An increasing number of companies now consider sustainability to be an important aspect of new product development, reputation building and overall corporate strategy (McKinsey 2010;

Communicated by Mohamed Ksibi, Co-Editor in Chief.

This paper was selected from the 2nd Euro-Mediterranean Conference for Environmental Integration (EMCEI), Tunisia 2019

Daizhong Su

Daizhong.su@ntu.ac.uk

1 School of Architecture, Design and the Built Environment, Nottingham Trent University, 50 Shakespeare Street, Nottingham NG1 4FQ, UK
Murto et al. 2014). In addition, many surveys and studies have shown that a growing number of consumers-especially millennials - are willing to pay extra for sustainable products and services, and expect companies to prioritise sustainability (Consumer Council 2016; Nielsen 2015). Furthermore, from the perspective of cost-effectiveness, companies have realised that sustainable production with a circular business model is economically beneficial, which is another key reason to adopt a sustainable programme (CountryProfiler 2018).

It is known that most of the potential negative environmental impacts associated with the manufacture and use phases of a product are prebuilt into the product. Environmental sustainability can be achieved for products and services by developing and optimising products that are more sustainable than the status quo (Boks and McAloone 2009; Seuring and Müller 2008). Eighty percent of the impact of a product is determined at the product design stage (Charter and Tischner 2001), so it is more effective for companies to address sustainability issues at the product development stage. However, companies are not taking a proactive approach to managing sustainability (McKinsey 2010). There may be several reasons for this. First, a lack of technical know-how within companies can prevent them from adopting sustainable measures. Assessment tools are required during sustainable product development or 
decision-making processes, but a large number of designers lack the skills needed to apply eco-design and related assessment tools. These barriers between designers/engineers and the relevant assessment tools have impeded the implementation of life-cycle thinking and sustainable product innovation (Millet et al. 2007). Second, a clear evidence-based design guide or approach for the specific product may not be available (Petersen 2017; Alblas et al. 2014). Third, the company may lack a comprehensive strategy (Brockhaus et al. 2016).

CIRC4Life (2018) is a large-scale collaborative project that aims to promote a novel circular economy approach to the life cycles of products and services and is supported by the European Commission's H2020 Circular Economy programme. Three new circular economy business models - the co-creation of products and services, sustainable consumption, and collaborative recycling and reuse-will be developed in the project. This approach will be demonstrated for four industrial sectors: industrial and domestic lighting, the meat supply chain, vegetable farming, and the recycling/reuse of computer tablets. Ona Product SL ("Ona") is a Spanish SME manufacturer of lighting products that specialises in domestic and contract lighting for hotels, leisure-related premises, offices, and public places (https://ona.es/). As part of the CIRC4Life project, Ona will demonstrate eco-design, sustainable production and eco-shopping for domestic LED lighting products using the methods developed by the project.

A number of studies have addressed environmental issues relating to LED lighting products. Most of the relevant literature are comparison studies of LED products and demonstrations of the energy efficiencies and environmental sustainabilities of different technologies or LED lighting products. Tähkämö et al. (2012) highlighted that modern light sources (CFLs and LEDs) are more environmentally friendly than conventional sources. Principi and Fioretti (2014) conducted a comparative life-cycle assessment of luminaires for office lighting and found that the environmental impact of a LED luminaire in the office was significantly lower than that of a compact fluorescent luminaire, mainly due to higher energy efficiency during the use stage. However, those studies were conducted by
LCA experts, and they were not performed to guide sustainable LED lighting product design. In one comparative LCA study (Casamayor et al. 2018) regarding design perspectives for LED lighting, the environmental impacts of a newly designed eco-LED product and a commercialised LED-based product were assessed and compared. The newly designed product was found to have a $60 \%$ lower environmental impact than the existing lighting product in all scenarios, and recommendations for the eco-design of LED lighting products were proposed.

The present study aimed to guide new eco-lighting product design by integrating life-cycle assessment (LCA) into the design process. By evaluating the environmental profiles of current products and then setting new product design specifications, issues and opportunities associated with the integration of LCA into domestic LED lighting eco-design were identified.

\section{Research method}

This study attempted to integrate the LCA methodology into eco-design methods and processes, as illustrated in Fig. 1. LCAs of existing products were initially conducted to evaluate their environmental profiles. In this case, the existing products were five domestic LED luminaires from Ona with model names of Embolic, Panau, Marble, Ele and Cobalt. All life-cycle stages were included in the LCA study to identify issues with and opportunities to improve environmental performance. Based on the results and interpretation, design reflections were generated with a view to conceiving an environmentally sustainable domestic LED luminaire design for Ona. Subsequently, the ecodesign of a domestic LED luminaire was carried out by integrating the reflections in accordance with the product design method. Finally, the validity of the design was confirmed by comparing the environmental performance of the new product with those of previous products using comparative LCA.

Fig. 1 Research method

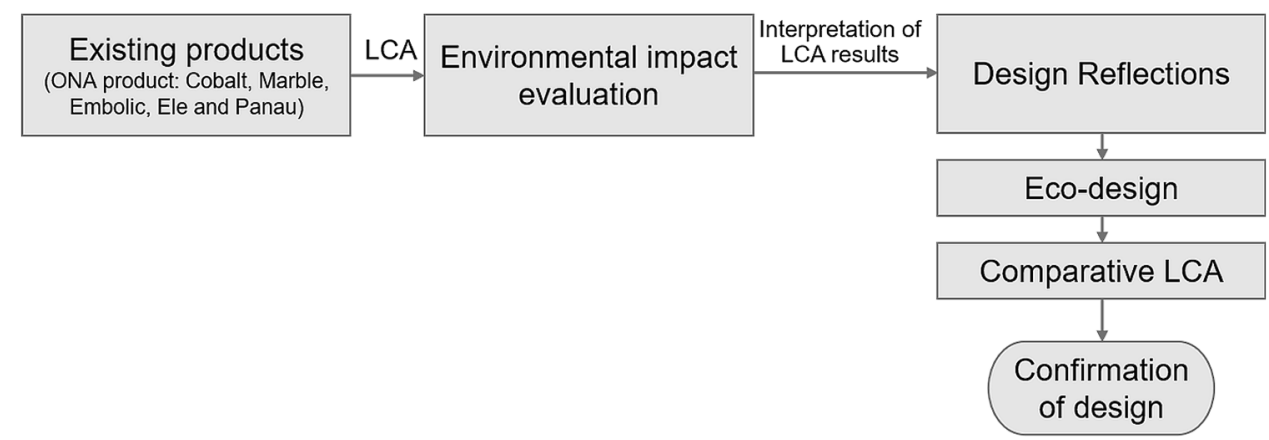




\section{Environmental impact analysis}

Life-cycle assessment (LCA) is an effective tool that allows the environmental impact of a product during its life cycle to be evaluated. It plays a significant role in environmentally responsible product innovation. In this study, five current domestic LED luminaires from Ona were assessed via screening LCA techniques in order to identify issues and opportunities associated with the integration of LCA into domestic LED lighting eco-design.

\section{Goal}

The goals of this work were to evaluate the overall environmental impacts of Ona's current products during their product life cycles and to identify key processes and key affecting factors behind the results.

\section{Functional unit}

The analysis focused on one unit of each of the five domestic LED luminaires: Embolic, Panau, Marble, Ele and Cobalt. Descriptions of these products are shown in Table 1.

\section{System boundary}

All life-cycle stages were taken into consideration in the assessment, including raw material extraction, the production of basic materials, the production of the components, assembly, the distribution (transportation) use stage, and end-of-life (EoL) treatment.

\section{Inventory data}

The lighting products were manufactured and assembled at Ona's plant in Spain. Data on the materials used, pre-product information, and energy consumption data were acquired through the data collection form and during interviews with the company engineers and managers. Background data on, for example, the extraction of raw materials and the production of basic materials were derived from the Ecoinvent 3.1 database. Inventory data are listed in Table 2. It was assumed that the luminaire would be used until the end of its useful life (i.e., for $40,000 \mathrm{~h}$ ).

\section{Life-cycle assessment}

The Online LCA Platform (https://h2020.circ4life.net/) was utilized to develop the assessment models for the products. This platform complies with ISO 14040 (ISO 2006) through the incorporation of the Ecoinvent 3.1 database (Ecoinvent
2007). The assessment models were developed by selecting the corresponding process data in the database and with adaptation of case-specific data (Goedkoop et al. 2009). This endpoint method scores a product based on 17 midpoint environmental categories, and then translates those scores into scores for three endpoint impacts-ecosystem, human health, and resources-via weighting and normalisation. To facilitate comparisons, the scores for the three endpoint impact categories for the product were summed to obtain a single score that represented the overall environmental impact of the product.

\section{Results}

Table 3 shows the single score results for the luminaires, along with data on the weight of each product and the number of materials used in it. The results show that Ele has the most negative score $(39 \mathrm{Pt})$ amongst the five variants, followed by Panau and Marble (37.7 Pt and 37.6 Pt, respectively). Cobalt and Embolic (scores: $22.5 \mathrm{Pt}$ and $27.4 \mathrm{Pt}$, respectively) have less of an environmental impact than the other three products. The scores appear to be correlated with weight and the number of materials used (see the "Results" section for more on this).

For each product, the total environmental impact was dominated by the impact of the product during its use stage, which was in turn due to the impacts of the production and consumption of electricity during the use stage. Figure 2 shows the Sankey diagram of total environmental impact for each product. In each diagram, the widest strip in each subfigure corresponds to the contribution of electricity production to the total impact of the product. This contribution is $97 \%, 95 \%, 88 \%, 94 \%$, and $97 \%$ of the total impact for Cobalt, Marble, Embolic, Ele, and Panau, respectively.

This allocation of impact among the life-cycle stages is considered reasonable for LED lighting products, and the use stage has been shown to be the key stage with respect to environmental impact in studies focusing on LEDs (Principi and Fioretti 2014; Casamayor et al. 2018). Moreover, in a LCA, electricity consumption is calculated by multiplying the service time by the power, so the longer that the product is used, the more electricity it consumes during its service life, and vice versa. One of the aims of the present study was to identify opportunities to improve product sustainability via product design. Therefore, it is important to set preferences to identify key processes that occur outside the use stage.

Table 4 lists the processes that are the main contributors to the total environmental impact of LED products aside from electricity usage. For Ele, the key processes are aluminium production, including the manufacture of the base parts $(80.9 \%$ of the total impact aside from electricity 
Table 1 Information on the products assessed

\begin{tabular}{|c|c|c|c|}
\hline Name & product Figure & Description & Specification \\
\hline Cobalt & & $\begin{array}{l}\text { Cobalt is a Pendant luminaire in } \\
\text { which wood and ceramics are } \\
\text { combined. With the floral drawing } \\
\text { in blue of the ceramic is inspired by } \\
\text { the Valencian ceramics. }\end{array}$ & $\begin{array}{l}\text { - Light body } \\
\text { height: } 20 \mathrm{~cm} \text {. } \\
\text { - Diameter: } \\
23 \mathrm{~cm} .\end{array}$ \\
\hline Marble & & $\begin{array}{l}\text { Table luminaire of large } \\
\text { dimensions joined with a } \\
\text { cylindrical foot of black marble } \\
\text { veined in white and a large glass } \\
\text { tulip, both elements make this } \\
\text { piece sculpture with great strength } \\
\text { and personality. }\end{array}$ & $\begin{array}{l}\text { - Total height: } \\
54 \mathrm{~cm} \text {. } \\
\text { - Diameter base } \\
\text { of marble: } \\
13.5 \mathrm{~cm} . \\
\text { - Diameter } \\
\text { glass diffuser: } \\
21 \mathrm{~cm} .\end{array}$ \\
\hline Panau & & $\begin{array}{l}\text { Pendant luminaire made with } \\
\text { natural fibres. With an original } \\
\text { design, it is suitable for any corner } \\
\text { of a house, providing a great } \\
\text { personality to the room and } \\
\text { pleasant light. }\end{array}$ & $\begin{array}{l}\text { - Height: } 50 \mathrm{~cm} \text {. } \\
\text { - Finish: } \\
\text { natural. } \\
\text { - System: E27. }\end{array}$ \\
\hline Embolic & (2) & $\begin{array}{l}\text { Good craftsmanship with offering a } \\
\text { warm and magical product that } \\
\text { skims the sculptural object. The } \\
\text { point of light illuminates the tangle } \\
\text { creating unique environments } \\
\text { among its shadows. The tangle is } \\
\text { solved by randomly interlaced } \\
\text { wooden slats suspended from a } \\
\text { steel wire illuminated from the } \\
\text { ceiling. }\end{array}$ & $\begin{array}{l}\text { - Height of the } \\
\text { led spotlight: } \\
8 \mathrm{~cm} \text {. } \\
\text { - Diameter of } \\
\text { the wooden } \\
\text { tangle: } 40- \\
45 \mathrm{~cm} .\end{array}$ \\
\hline Ele & & $\begin{array}{l}\text { The aesthetics of this table } \\
\text { luminaire is characterized by its } \\
\text { simplicity. Designed with straight } \\
\text { lines and with a shape that reminds } \\
\text { us of the consonant L, it makes it a } \\
\text { great looking luminaire in an } \\
\text { apartment where it is placed. }\end{array}$ & $\begin{array}{l}\text { - Height: } 43 \mathrm{~cm} \\
\text { - Width: } 40 \mathrm{~cm} . \\
\text { - Screen height: } \\
22 \mathrm{~cm} . \\
\text { - Finishing } \\
\text { structure: matt } \\
\text { metal. } \\
\text { - Finishing } \\
\text { screen: white } \\
\text { parchment. }\end{array}$ \\
\hline
\end{tabular}

stage and end-of-life (EoL) treatment. 
Table 2 Inventory data for the luminaires studied in this work

\begin{tabular}{|c|c|c|c|c|c|c|c|c|c|}
\hline \multicolumn{2}{|l|}{ Marble } & \multicolumn{2}{|l|}{ Embolic } & \multicolumn{2}{|l|}{ Panau } & \multicolumn{2}{|l|}{ Cobalt } & \multicolumn{2}{|l|}{ Ele } \\
\hline Marble base & $2.13 \mathrm{~kg}$ & Wood & $1.136 \mathrm{~kg}$ & Wood & $0.475 \mathrm{~kg}$ & Wood piece & $0.025 \mathrm{~kg}$ & Aluminium & $3.755 \mathrm{~kg}$ \\
\hline Glass tulip & $2.2 \mathrm{~kg}$ & Cable & $0.7 \mathrm{~kg}$ & Cable & $0.7 \mathrm{~kg}$ & Cable & $0.058 \mathrm{~kg}$ & Cable & $0.094 \mathrm{~kg}$ \\
\hline Cables & $0.15 \mathrm{~kg}$ & $\begin{array}{c}\text { Road trans- } \\
\text { portation }\end{array}$ & $674.5 \mathrm{~kg} \mathrm{~km}$ & Plastic & $0.025 \mathrm{~kg}$ & $\begin{array}{l}\text { Ceramic } \\
\text { part }\end{array}$ & $0.542 \mathrm{~kg}$ & Plastic & $0.316 \mathrm{~kg}$ \\
\hline $\begin{array}{l}\text { Metal parts } \\
\text { (steel) }\end{array}$ & $0.155 \mathrm{~kg}$ & $\begin{array}{l}\text { Electricity, } \\
\text { low volt- } \\
\text { age }\end{array}$ & $280 \mathrm{kWh}$ & Metal piece & $0.05 \mathrm{~kg}$ & Wood part & $0.291 \mathrm{~kg}$ & Lamp frame & $0.028 \mathrm{~kg}$ \\
\hline $\begin{array}{l}\text { Road trans- } \\
\text { portation }\end{array}$ & $1547.8 \mathrm{~kg} \mathrm{~km}$ & $\begin{array}{l}\text { End of life } \\
\text { (multiple } \\
\text { waste } \\
\text { treatment) }\end{array}$ & $1.836 \mathrm{~kg}$ & $\begin{array}{c}\text { Road trans- } \\
\text { portation }\end{array}$ & $674.5 \mathrm{~kg} \mathrm{~km}$ & $\begin{array}{l}\text { Lamp } \\
\text { holder }\end{array}$ & $0.013 \mathrm{~kg}$ & Steel parts & $0.014 \mathrm{~kg}$ \\
\hline $\begin{array}{l}\text { Electricity, } \\
\text { low volt- } \\
\text { age }\end{array}$ & $400 \mathrm{kWh}$ & & & $\begin{array}{l}\text { Electricity, } \\
\text { low volt- } \\
\text { age }\end{array}$ & $400 \mathrm{kWh}$ & $\begin{array}{l}\text { Road trans- } \\
\text { portation }\end{array}$ & $1355 \mathrm{~kg} \mathrm{~km}$ & $\begin{array}{l}\text { Electricity, } \\
\text { low volt- } \\
\text { age }\end{array}$ & $400 \mathrm{~kW} \mathrm{~h}$ \\
\hline \multirow[t]{2}{*}{$\begin{array}{l}\text { End of life } \\
\text { (multiple } \\
\text { waste } \\
\text { treatment) }\end{array}$} & $4.36 \mathrm{~kg}$ & & & $\begin{array}{l}\text { End of life } \\
\text { (multiple } \\
\text { waste } \\
\text { treatment) }\end{array}$ & $1.836 \mathrm{~kg}$ & $\begin{array}{l}\text { Electricity, } \\
\text { low volt- } \\
\text { age }\end{array}$ & $400 \mathrm{kWh}$ & $\begin{array}{c}\text { Road trans- } \\
\text { portation }\end{array}$ & $1493.5 \mathrm{~kg} \mathrm{~km}$ \\
\hline & & & & & & $\begin{array}{l}\text { End of life } \\
\text { (multiple } \\
\text { waste } \\
\text { treatment) }\end{array}$ & $0.95 \mathrm{~kg}$ & End of life & $4.307 \mathrm{~kg}$ \\
\hline
\end{tabular}

Table 3 Endpoint single-score results for the five luminaires

\begin{tabular}{llll}
\hline Product name & $\begin{array}{l}\text { Single score } \\
\text { result }(\mathrm{Pt})\end{array}$ & $\begin{array}{l}\text { Product mass } \\
(\mathrm{kg})\end{array}$ & $\begin{array}{l}\text { Number of } \\
\text { materials } \\
\text { used }\end{array}$ \\
\hline Cobalt & 22.5 & 0.95 & 4 \\
Marble & 37.6 & 4.36 & 4 \\
Panau & 37.7 & 1.25 & 4 \\
Embolic & 27.4 & 1.84 & 2 \\
Ele & 39 & 4.39 & 4 \\
\hline
\end{tabular}

usage), the cable (11.61\%), and other components, including the plug and the lamp frame (1.49\%).

For Panau, the production process for the communication cable is a major contributor to the overall impact (it contributes $90.27 \%$ of the total impact if electricity usage is ignored), while disposal of the lighting product is another important contributor $(4.15 \%)$. Because relatively small amounts of plastic, steel and wood are used in Panau, the impact of those materials is minor $(2.18 \%$ in total).

The tangled wooden part $(57.49 \%$ of the total impact ignoring electricity usage) and cable production (40.35\%) are the key contributors to the impact of Embolic. Aside from the cable, which accounts for $49.72 \%$ of the total impact of Cobalt (electricity usage aside), the production of the ceramic and wooden parts as well as the transportation and disposal of the product after it has been used contribute more than half of the total impact of Cobalt (50.28\%).
Similarly, the production of the glass lampshade $(30.22 \%$ of the total impact if electricity usage is ignored), the end-oflife treatment of the product $(25.71 \%)$, and cable production $(31.45 \%)$ are key processes in terms of their contributions to the overall environmental impact of Marble. Transportation of the product is another notable process $(10.28 \%$ of the overall impact aside from electricity usage) in this context due to the weight of the product and the way that it is packaged.

\section{Interpretation and reflection}

The LCA results indicate the issues and potential risks associated with Ona's current product range:

- Complex to manufacture. According to the assessment results, Marble and Panau have almost the same total impact (37.6 and 37.7, respectively), and both consist of four kinds of materials. However, due to the complexity of its production process, Panau has a slightly higher impact than Marble even though Marble is nearly four times heavier than Panau $(4.36 \mathrm{~kg}$ and $1.1 \mathrm{~kg}$, respectively). The energy consumed during the production of Panau is the main reason for its high environmental impact.

- Product weight. Total product weight is another variable that affects the total environmental performance of 


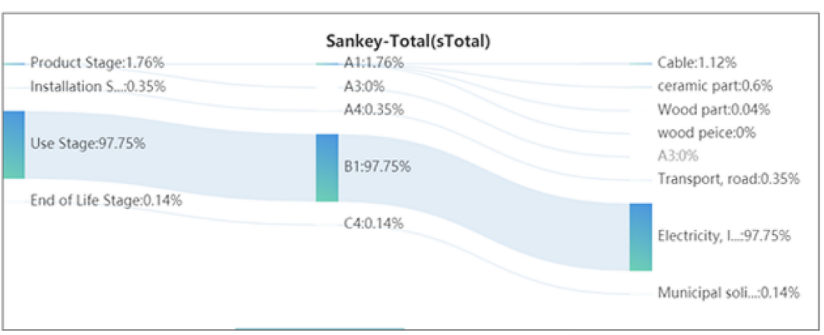

(a) Cobalt

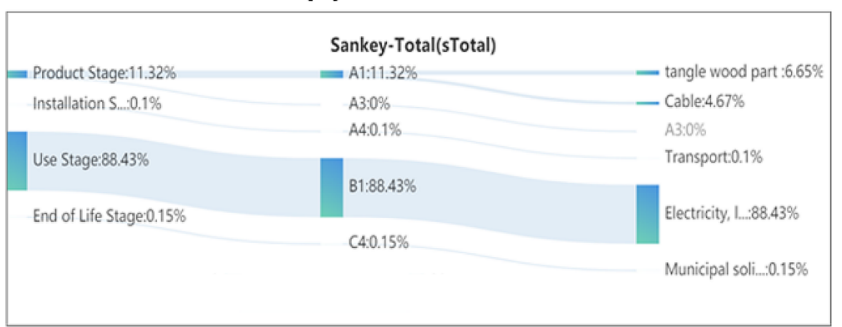

(c) Embolic

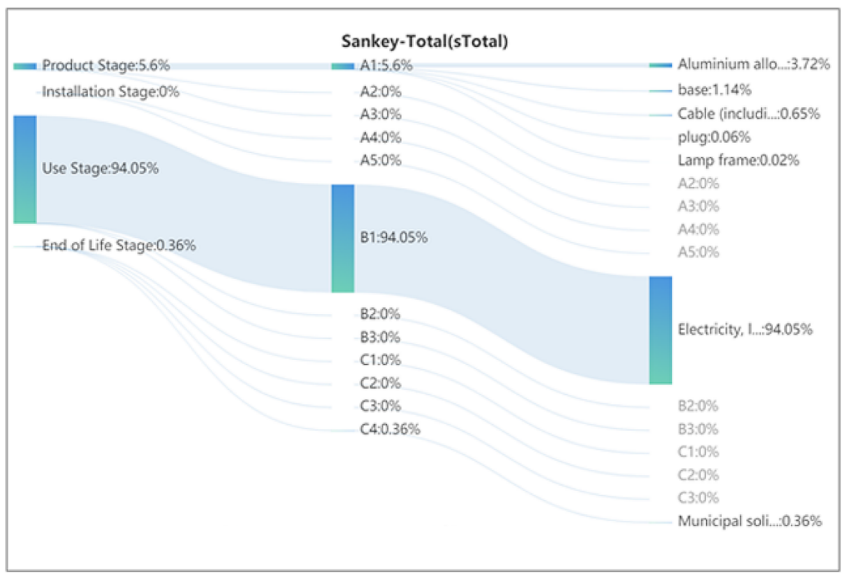

(e) Ele

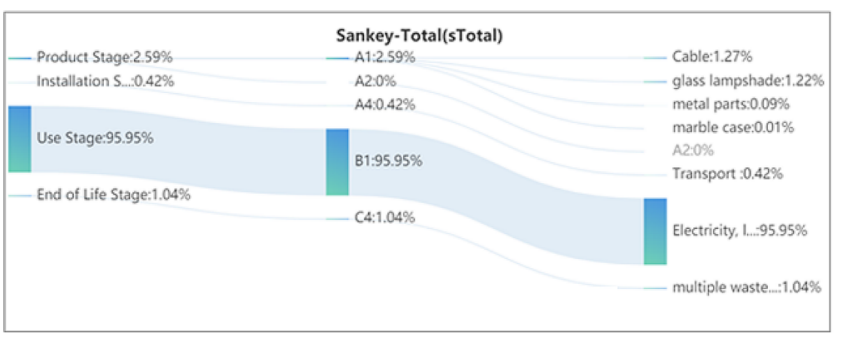

(b) Marble

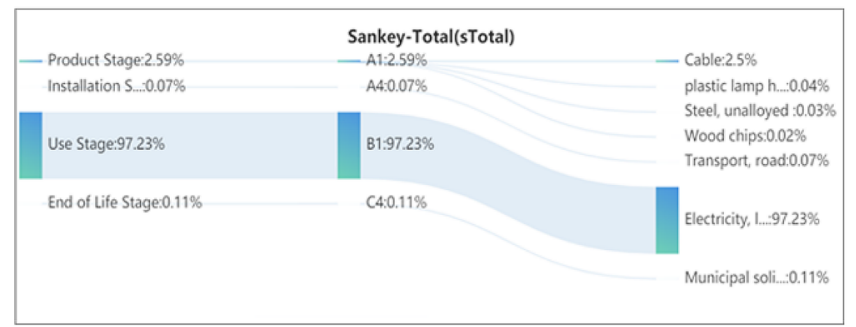

(d) Panau

\section{A - production stage \\ $B$ Use stage \\ $\mathrm{C}$ - End of life stage}

Fig. 2 Sankey diagrams of total environmental impact for the five luminaires

a product. The results show that Marble and Ele have relatively high impacts (39 and 37.6, respectively) as they are heavy in comparison with the other products studied here. In contrast, Cobalt boasts the best environmental performance (22.5) amongst the five products, as it is lightweight.

- Hard to assemble or disassemble. According to Ona, all the products are preassembled and then transported. This approach can increase the production complexity and impede recycling/reuse. For instance, the product cannot be recycled/reused if parts cannot be detached, even if the materials used in the product are recyclable/ reusable. Furthermore, a product that is hard to assemble/ disassemble is also unlikely to be repairable if there is a fault with the product. This may lead to a shorter service life. Preassembly may also decrease the transportation efficiency, increasing transportation costs.
- Lack of consideration of the end-of-life phase. End-of-life (EoL) options for the product must be considered when choosing the construction materials, jointing method and the finish of the product. Currently, each lamp product (i.e. the housing materials used in the product) is disposed of at the end-user side when it reaches the end of its service life. Better EoL solutions that increase the possibility that the housing materials will be recycled/ reused can be planned at the design stage.

In addition, the selection of low environmental impact materials and the utilisation of a low number of construction materials have a positive influence on the environmental performance. Embolic has a relatively low impact as it is made from low environmental impact materials (wood), has a low mass, and is constructed in a relatively simple manner. However, as seen in Table 3, the impact of Panau is $27 \%$ higher 
Table 4 Key processes (aside from electricity usage) in terms of their contributions to the overall environmental impact of each LED product

\begin{tabular}{llc}
\hline Product (luminaire) & Process & Contribution \% \\
\hline Ele & Aluminium alloy & 66.46 \\
& Base (aluminium) & 20.44 \\
& Cable (including socket) & 11.61 \\
& Plug & 1.11 \\
Panau & Lamp frame & 0.38 \\
& Cable & 90.27 \\
& Municipal solid waste & 4.15 \\
Embolic & Transport, road & 2.4 \\
& Plastic lamp holder & 1.36 \\
& Steel, unalloyed & 1.24 \\
& Tangled wooden part & 57.49 \\
Cobalt & Cable & 40.35 \\
& Municipal solid waste & 1.31 \\
& Transport & 0.85 \\
& Cable & 49.72 \\
Marble & Ceramic part & 26.53 \\
& Transport, road & 15.73 \\
& Municipal solid waste & 6.25 \\
& Wooden part & 1.65 \\
& Cable & 31.45 \\
& Glass lampshade & 30.22 \\
& Multiple waste treatment & 25.71 \\
& Transport & 10.28 \\
& & 2.15 \\
\hline \multirow{4}{*}{ Metal parts } & \\
& & \\
& & \\
& &
\end{tabular}

than that of Embolic, even though both products are mainly made from wood and Panau is not as heavy as Embolic. The reason for this may be the diversity of materials used in Panau. This product is constructed from four main materials, whereas Embolic is constructed from two materials, meaning that more manufacturing processes and resources are needed to construct Panau, which in turn increases its environmental impact. There are other potential sustainability issues with the use of a relatively large number of construction materials too. For example, the utilisation of a considerable number of materials may influence the selection of the method used to join together different assembly parts, may make the product more complicated to manufacture, and may impede assembly and disassembly. It is also apparent that, except for Embolic, all of the luminaires that are currently produced by Ona are constructed from four kinds of main materials. Although the use of a wide range of materials in the design can help to achieve the aesthetic goal of the product, our results suggest that low environmental impact materials should be employed in the new luminaire design where possible, and that the number of materials used in the new design should be minimised.

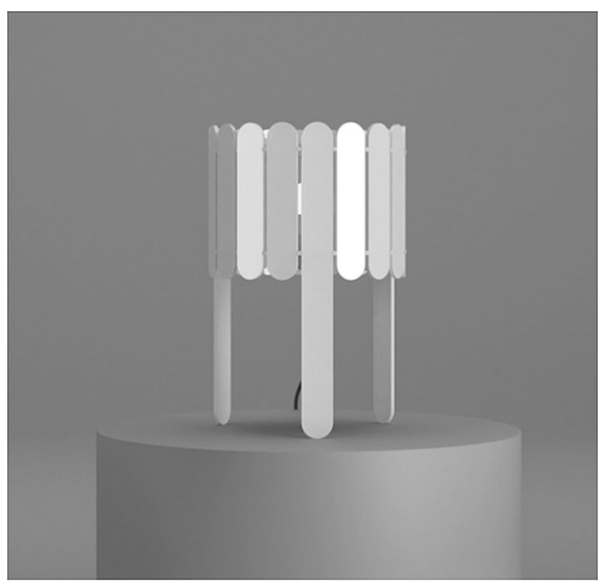

Fig. 3 Eco-design of a new LED lighting product

\section{Eco-design of a new LED lighting product}

Taking the assessment results and reflections into account, product design specifications (PDS) for a new LED lighting product were devised in accordance with standard PDS requirements (Pugh 1991). To ensure that this paper is not an excessive length, we list only the key characteristics defined in the PDS below:

- Low energy consumption during the manufacturing stage (easy to manufacture)

- Prolong the lifespan by enabling repairability - the product is expected to have a 10-year lifespan

- Modular design

- Easy to assemble/disassemble (the consumer can assemble the product by themselves)

- Made from low-impact materials; postconsumer/recycled materials are preferred

- Refine the dimensions of the product to reduce weight

- Fully recyclable at end of life

- Flat packaging.

Based on the PDS, the new table lamp shown in Fig. 3 was developed. The proposed eco-design principle was embodied in the new product through the use of a modular housing made entirely of extruded postconsumer recycled materials. The electrics (including the LEDs and the driver) used in the new lamp are designed to be compliant with RoHS. Two correlated colour temperatures (CCTs), $3000 \mathrm{~K}$ (warm light) and $5000 \mathrm{~K}$ (cold light), are applied alternately. A dimmable feature with driver circuit control is also included. The sustainability of the lamp is addressed through the following characteristics:

- High-availability material. The default material used in the design is postconsumer plastic. There are three addi- 
tional material options to meet wider customer needs: wood, metal, and glass. The chosen materials are all standard materials that are readily available and easy to recycle.

- Modular structure. The goal of eco-design is to achieve a simple structure that uses relatively few materials but is still visually appealing to consumers. The external structure of the lamp is constructed from multiple pieces of the same shape and size. These pieces are joined to two internal rings. The outer pieces are curved at the ends for safety and aesthetic reasons. The modular structure of the lamp also makes it easy to assemble/disassemble the lamp (the consumer can assemble the lamp by themselves) and to access the inner parts of the lamp when repairs are needed or for maintenance purposes.

- Easy to manufacture. The main pieces used in the lamp are all made from postconsumer recycled materials that are processed using extrusion. No joint members are required, reducing the complexity of the lamp as well as the energy consumption during manufacture. A special adhesive is used to join the pieces together. One novel aspect of the design is that chemicals can be used to dissolve the adhesive, thus circumventing a potential hindrance to disassembly and recycling.

- High recyclability/reusability. The whole lamp is made from just one material without no additional joint members (although there are three material options). Therefore, the lamp can be recycled as a whole-it does not need to be disassembled before passing through the WEEE procedure during its EoL stage.

\section{Comparison of LCA results}

One unit of the new eco-designed LED lighting product constructed from the default material (plastic) was assessed using the same life-cycle impact assessment (LCIA) method as applied to the other lighting products. During the assessment, it was assumed that the new product would be transported the same distance and have the same service life $(40,000 \mathrm{~h})$ as the current products, and that the whole lamp housing would be recycled at the end of the new product's service life.

Table 5 shows the endpoint results from the online LCA platform. The total impact of the eco-design lamp is 16.4 (Pt). Human health is the most affected impact category $(10.9 \mathrm{Pt})$, followed by resources $(4.98 \mathrm{Pt})$. The impact on the ecosystem is minimal $(0.528 \mathrm{Pt})$.

Figure 4 compares the five products considered in this work in terms of environmental impact score from endpoint assessment, product weight, and number of construction materials used. The newly designed lamp presents the lowest impact score, $16.4 \mathrm{Pt}$, which is $27 \%$ less than that of Cobalt
Table 5 Endpoint single-score results for the newly designed lamp product

\begin{tabular}{llc}
\hline Characterization & Explanation & Value $(\mathrm{Pt})$ \\
\hline sTotal & Total & 16.4 \\
sHH & Human health & 10.9 \\
sES & Ecosystems & 0.528 \\
sRS & Resources & 4.98 \\
\hline
\end{tabular}

and $58 \%$ less than that of Ele. It is also the lightest of the five products $(0.8 \mathrm{~kg})$ and is made from the fewest types of materials (just one).

However, LCA is a quantitative method of evaluating numerical process data. Some qualitative eco-features cannot be assigned numerical values, so they cannot be included in a LCA. For instance, the eco-designed lamp product is easy to transport, easy to disassemble and repair, takes up a relatively small volume during delivery, and requires relatively little packaging material. These eco-features greatly enhance the eco-performance of the proposed product by saving energy or improving product usability, but they were not taken into account during the assessment due to the quantitative nature of LCA.

\section{Conclusion}

In this study, an approach for integrating LCA into the eco-design of lighting products was developed. To test this approach, LCAs of five lighting products that are currently on the market were performed. Issues with the environmental performance of the products were identified, along with opportunities to improve that performance. Evidence-based reflections were generated and integrated into the eco-design of domestic LED lighting products. The new lamp design that was produced using this approach was found to have a better environmental performance than the other products, as well as other (more qualitative) eco-features.

The environmental assessment results showed that Ele has the most negative impact score (39 Pt) among the five domestic LED luminaires, followed by Panau and Marble (37.7 Pt and 37.6 Pt, respectively), while Cobalt (22.5 $\mathrm{Pt})$ and Embolic $(27.4 \mathrm{Pt})$ have relatively low impacts. The consumption of electricity during the use stage was the main contributor to the environmental impact of each product: it accounted for more than $90 \%$ of the total impact of each product on average. Analyses were also conducted to identify the key variables behind the impacts of the current products. It was found that (1) the complexity of the product manufacturing process, (2) the product weight, (3) the difficulty involved in assembling or disassembling the product, (4) the variety of construction materials used 
Fig. 4 Comparison of the five lighting products considered in this work in terms of environmental impact score, product weight, and number of construction materials used

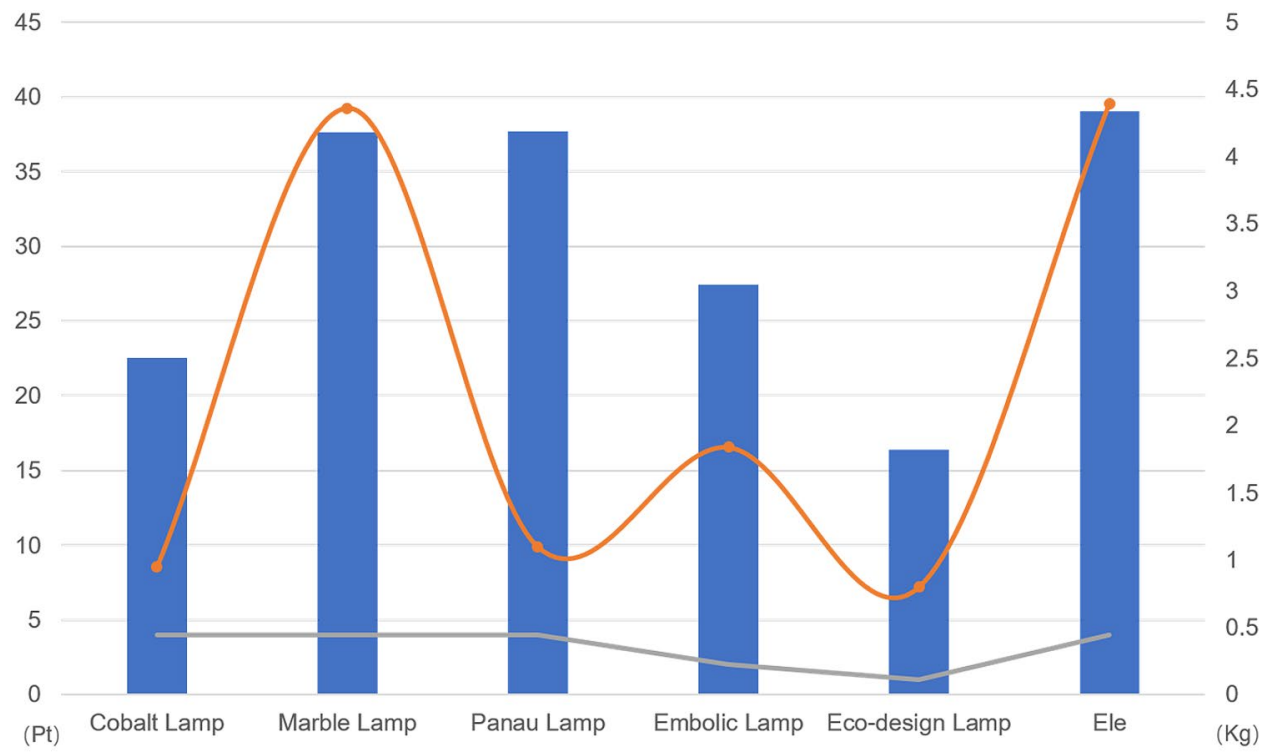

Environmental impact (Endpoint single score) and (5) a lack of consideration of the product's end-of-life phase are the main issues that affect the environmental profile of a lighting product. Therefore, these were the main issues addressed during eco-design innovation.

A LED lamp product was eco-designed by integrating the design reflections into the PDS. Several eco-features were incorporated into the lamp, especially the reduced use of materials. A comparison of the LCA results for the new and current lighting products indicated that the eco-designed lamp yielded the best environmental performance-it had the lowest impact score, $16.4 \mathrm{Pt}$, which was $27 \%$ less than that of Cobalt and $58 \%$ less than that of Ele. Additionally, the new lamp is the least heavy $(0.8 \mathrm{~kg})$ of the products and is constructed from the fewest materials (just one).

It can be concluded that the integration of LCA in the product design process for PDS development and decisionmaking is an effective means in developing environmentfriendly LED lighting product.

Acknowledgements The author acknowledges the contributions and support from Ona Product SL, Valencia, Spain. This work was supported by the European Commission Horizon 2020 Circular Economy programme for the CIRC4Life project (Grant agreement number: 776503).

\section{Compliance with ethical standards}

Conflict of Interest On behalf of all authors, the corresponding author states that there is no conflict of interest.
Open Access This article is licensed under a Creative Commons Attribution 4.0 International License, which permits use, sharing, adaptation, distribution and reproduction in any medium or format, as long as you give appropriate credit to the original author(s) and the source, provide a link to the Creative Commons licence, and indicate if changes were made. The images or other third party material in this article are included in the article's Creative Commons licence, unless indicated otherwise in a credit line to the material. If material is not included in the article's Creative Commons licence and your intended use is not permitted by statutory regulation or exceeds the permitted use, you will need to obtain permission directly from the copyright holder. To view a copy of this licence, visit http://creativecommons.org/licenses/by/4.0/.

\section{References}

Alblas A, Peters K, Wortmann H (2014) Fuzzy sustainability incentives in new product development-an empirical exploration of sustainability challenges in manufacturing companies. Int $\mathbf{J}$ Oper Prod Manag 34:513-545. https://doi.org/10.1108/IJOPM $-10-2012-0461$

Boks C, McAloone TC (2009) Transitions in sustainable product design research. Int J Prod Dev 9:429-449. https://doi.org/10.1504/ IJPD.2009.027475

Brockhaus S, Petersen M, Kersten W (2016) A crossroads for bioplastics: exploring product developers' challenges to move beyond petroleum-based plastics. J Clean Prod 127:84-95. https://doi. org/10.1016/j.jclepro.2016.04.003

Casamayor JL, Su DZ, Ren ZM (2018) Comparative life cycle assessment of LED lighting products. Lighting Res Technol 50:801826. https://doi.org/10.1177/1477153517708597

Charter M, Tischner U (2001) Sustainable solutions: developing products and services for the future. Greenleaf, Sheffield

CIRC4Life (2018) Grant agreement number: 776503 - CIRC4LifeH2020-IND-CE-2016-17/H2020-CIRC-2017. European Commission, Brussels 
Climate Action (2015) UN Framework on Climate Change (UNFCCC). https://www.cop21paris.org/about/cop21. Accessed 8 Jan 2019

Consumer Council (2016) Sustainable consumption for a better future-a study on consumer behaviour and business reporting. Consumer Council, Hong Kong

CountryProfiler (2018) Sustainability-the new normal. Malta 2018 feature. CountryProfiler Ltd., Malta. https://www.countryprofiler .com/. Accessed 20 Nov 2019

Ecoinvent (2007) Ecoinvent - the world's most consistent \& transparent life-cycle inventory database. https://www.ecoinvent.org/ home.html. Accessed 6 Nov 2019

Goedkoop M, Heijungs R, Huijbregts M, Schryver AD, Struijs J, Zelm RV (2009) ReCiPe 2008. https://www.leidenuniv.nl/cml/ssp/publi cations/recipe_characterisation.pdf. Accessed 8 Jan 2019

ISO (2006) ISO 14040:2006-Environmental management: life cycle assessment: principles and framework. International Organization for Standardization, Geneva. https://www.iso.org/standard/37456 .html?browse $=$ tc. Accessed 3 Mar 2018

LeBlanc R (2018) Top business sustainability trends for 2018. https ://www.thebalancesmb.com/top-business-sustainability-trend s-4121259. Accessed 8 Jan 2019

McKinsey (2010) How companies manage sustainability: McKinsey Global Survey results. https://www.mckinsey.com/business-funct ions/sustainability-and-resource-productivity/our-insights/howcompanies-manage-sustainacility-mckinsey-global-survey-resul ts. Accessed 20 Jun 2018

Millet D, Bistagnino L, Lanzavecchia C, Camous R, Poldma T (2007) Does the potential of the use of LCA match the design team needs? J Clean Prod 15:335-346. https://doi.org/10.1016/j.jclep ro.2005.07.016
Murto P, Person O, Ahola M (2014) Shaping the face of environmentally sustainable products: image boards and early consumer involvement in ship interior design. J Clean Prod 75:86-95. https ://doi.org/10.1016/j.jclepro.2014.03.078

Nielsen (2015) The sustainability imperative-new insights on consumer expectations. The Nielsen Company, New York. https:// www.nielsen.com/eu/en/insights/report/2015/the-sustainabilityimperative-2/. Accessed 20 Sep 2019

Pacheco-Blanco B, Bastante-Ceca MJ (2016) Green public procurement as an initiative for sustainable consumption. An exploratory study of Spanish public universities. J Clean Prod 133:648-656. https://doi.org/10.1016/j.jclepro.2016.05.056

Petersen M (2017) Considering sustainability in the development of consumer goods. PhD thesis. Technischen Universität Hamburg, Hamburg. https://doi.org/10.15480/882.1357

Principi P, Fioretti R (2014) A comparative life cycle assessment of luminaires for general lighting for the office-compact fluorescent (CFL) vs light emitting diode (LED) — a case study. J Clean Prod 83:96-107. https://doi.org/10.1016/j.jclepro.2014.07.031

Pugh S (1991) Total design: integrated methods for successful product engineering. Prentice Hall

Seuring S, Müller M (2008) From a literature review to a conceptual framework for sustainable supply chain management. J Clean Prod 16:1699-1710. https://doi.org/10.1016/j.jclepro.2008.04.020

Tähkämö L, Puolakka M, Halonen L, Zissis G (2012) Comparison of life cycle assessments of LED light sources. J Light Vis Environ 36:44-53. https://doi.org/10.2150/jlve.36.44 